\title{
Inovasi Pengembangan Kurikulum Sekolah Berbasis Pesantren dalam Meningkatkan Kepercayaan Masyarakat
}

\author{
Muhammad Munif ${ }^{1}$, Fathor Rozi ${ }^{2}$, Moh. Aminullah ${ }^{3}$ \\ Universitas Nurul Jadid \\ m.munifmpdi@gmail.com,fathorrozi330@gmail.com
}

\begin{abstract}
This study aims to find out innovations in developing a pesantren-based school curriculum in increasing public confidence in SMP Islam Sumberranyar Paiton Probolinggo. This research uses a qualitative approach, while the type of research used is a case study. The results of the study show that: innovations in developing pesantren-based school curriculum in increasing public trust are as follows; The innovation of developing a pesantren-based school curriculum in Islamic junior high schools has improved very well, from the development of the school curriculum trying to develop a pesantren curriculum by changing the learning system, the supporting factors for innovation in developing a pesantren-based school curriculum in Islamic junior high schools include the principal involving all relevant stakeholders, both administrators and administrators. The entire board of teachers, community leaders, guardians of students as well as support from boarding school caregivers, inbibiting factors for innovation in developing a pesantren-based school curriculum in Islamic junior bigh schools, the low awareness of teachers to develop learning tools, this hampers the innovation of developing a pesantren-based school curriculum which was developed together at Sumberanyar Islamic Middle School Paiton, while the positive impact of curriculum innovation developed at Islamic Junior High School can increase public confidence in Sumberanyar Islamic Junior High School Paiton Probolinggo
\end{abstract}

Keyword : Curriculum Development, Islamic Boarding School Based Schools, Community Trust

\begin{abstract}
Abstrak : Penelitian ini bertujuan untuk mengetahui inovasi pengembangan kurikulum sekolah berbasis pesantren dalam meningkatkan kepercayaan masyarakat di SMP Islam Sumberranyar Paiton Probolinggo. Penelitian ini menggunakan pendekatan kualitatif, sedangkan jenis penelitian yang digunakan adalah studi kasus. Hasil penelitian menunjukkan bahwa: inovasi pengembangan kurikulum sekolah berbasis pesantren dalam meningkatkan kepercayaan masyarakat, sebagai berikut; inovasi pengembangan kurikulum sekolah berbasis pesantren di SMP Islam mengalami peningkatan yang sangat baik, dari pengembangan kurikulum sekolah berusaha mengembangkan kurikulum pesantren dengan merubah sistem pembelajaran, faktor pendukung inovasi pengembangan kurikulum sekolah berbasis pesantren di SMP Islam antara lain kepala sekolah merlibatkan semua stakeholder yang terkait baik pengurus,segenap dewan guru tokoh masyarakat wali murid serta dukungan dari pengasuh pondok pesantren, faktor penghambat inovasi pengembangan kurikulum sekolah berbasis pesantren di SMP Islam rendahnya kesadaran guru untuk mengembangkan perangkat pembelajaran hal ini menghambat Inovasi pengembangan kurikulum sekolah berbasis pesantren yang di kembangkan bersama di SMP Islam Sumberanyar Paiton,
\end{abstract}

MANAZHIM : Jurnal Manajemen dan Ilmu Pendidikan

Volume 3, Nomor 2, Agustus 2021; 183-200

https:// ejournal.stitpn.ac.id/index.php/manazhim 
sedangkan dampak positif Inovasi kurikulum yang di kembangkan di SMP Islam dapat meningkatan kepercayaan masyarakat pada SMP Islam Sumberanyar Paiton Probolinggo

Kata Kunci : Pengembangan Kurikulum, Sekolah Berbasis Pesantren, Kepercayaan Masyarakat

\section{PENDAHULUAN}

Pendidikan dan kurikulum merupakan hal yang tidak bisa dipisahkan, ini karena kurikulum dengan pendidikan memiliki keterkaitan satu sama lain. Ini sejalan dengan para pakar pendidikan yang menyatakan bahwa fungsi utama sekolah adalah pembinaan dan pengembangan semua potensi individu, terutama pengembangan potensi fisik, intelektual, dan moral peserta $\operatorname{didik}^{1}$.

Pengembangan kurikulum merupakan hal yang harus dilakukan oleh setiap sekolah bertujuan agar tujuan pendidikan dapat tercapai secara maksimal. Kurikulum berfungsi sebagai sumber kegiatan akademis untuk mencapai tujuan pendidikan. Munculnya penemuan-penemuan baru dalam segala bidang kehidupan merupakan prestasi kalangan pendidikan. Karenanya kurikulum hendaknya lebih berorientasi ke masa depan dan kepentingan anak didik, sesuai dengan tantangan zaman modern yang mementingkan prestasi bukan prestise ${ }^{2}$.

Keberadaan kurikulum sebagai landasan utama pendidikan selalu menuntut perubahan-perubahan yang signifikan dari masa ke masa. Sebab seiring perkembangan ilmu pengetahuan maka kurikulum pun harus dinamis dan membutuhkan sentuhan inovasi agar mampu mengimbangi kemajuan tersebut. Bahkan kurikulum dapat berubah secara fundamental jika memang suatu negara atau otoritas mengalami perubahan ${ }^{3}$. Hal itu berarti pada dasarnya gerak dinamika kurikulum memang merupakan sesuatu yang alami dan

\footnotetext{
1 Mursalim and Hatta, 'Inovasi Pengembangan Kurikulum PAI Di Sekolah Menengah Pertama Raudatut Tholabah Berbasis Pesantren', Journal of Islamic Education Research, 1.02 (2020), 1-14 $<$ https://doi.org/10.35719/jier.v1i02.23>.

${ }^{2}$ Nurul Huda, 'Manajemen Pengembangan Kurikulum', Al-Tanzim : Jurnal Manajemen Pendidikan Islam, 1.2 (2017), 52-75 < https://doi.org/10.33650/al-tanzim.v1i2.113>.

3 Ali Mustofa, 'Perkembangan Kurikulum Pendidikan Agama Islam Di Pesantren, Madrasah Dan Sekolah', Jurnal Pikir: Jurnal Studi Pendidikan Dan Hukum Islam, 1.2 (2015), 89-121.
} 
diharapkan, karena struktur ilmu pengetahuan terus bergerak maju dan kurikulum mesti berbanding lurus.

Berbicara dalam konteks kurikulum, maka inovasi dapat diartikan sebagai pengembangan, pembaharuan, memasukkan hal baru ke dalam proses belajar mengajar, sistem pengajaran dan segala sesuatu yang terkait dengan pendidikan ${ }^{4}$.

Fenomena kurang baik yang sering dijumpai dalam kaitannya dengan kurikulum, adanya pemisahan sistematis antara ilmu-ilmu umum dan ilmu-ilmu agama. Padahal kurikulum yang baik haruslah saling mengisi, tidak boleh ada dikotomi antara kedua jenis disiplin ilmu yang berlainan tersebut. Lebih jauh beliau menyatakan, ilmu dan iman (agama) akan saling menguatkan ${ }^{5}$. Tidak berbeda dengan pendapat Abuddin, Agil menyatakan bahwa, ilmu-ilmu yang mampu mengangkat kualitas hidup manusia secara lahiriya dipandang perlu untuk diintegrasikan dengan ilmu-ilmu yang membawa kesejahteraan batin, karena pada dasarnya semua ilmu merupakan anugerah Allah SWT. ${ }^{6}$

Kesadaran beberapa sekolah untuk memasukkan ilmu eksakta ke dalam kurikulumnya merupakan langkah inovatif yang pantas diapresiasi. Tidak mudah untuk mengkombinasikan ilmu pengetahuan keagamaan dengan ilmu pengetahuan umum dalam sebuah konsep integral. Memang titik pusat kajian keilmuan di pondok pesantren merupakan ilmu-ilmu agama. Tetapi ilmu agama ini tidak akan berkembang dengan baik tanpa ditunjang ilmu-ilmu lain seperti ilmu sosial dan ilmu alam? Harus ditekankan bahwa ilmu-ilmu tersebut hanya penunjang, ini yang mesti diyakini oleh kalangan pendidik konservatif yang selalu memberi stigma bahwa ilmu selain keagamaan tidak penting dipelajari.

Selain mengesampingkan dikotomi pengetahuan, pengembangan kurikulum memiliki landasan strategis yaitu harus disadari bahwa kurikulum disusun guna mewujudkan tujuan pendidikan nasional dengan memperhatikan tahap

4 Hermanto Halil, 'Inovasi Kurikulum Pesantren Dalam Memproyeksikan Model Pendidikan Alternatif Masa Depan', Studi Keislaman, 1.2 (2015), 1-23.

5 Muhtifah.

${ }^{6}$ Kusnandi Kusnandi, 'Integrasi Kurikulum Berbasis Pesantren Pada Lembaga Pendidikan', Jurnal Kependidikan, 5.2 (2017), 279-97 < https://doi.org/10.24090/jk.v5i2.2138>.

${ }^{7}$ Moch. Sya'roni Hasan and Nur Arifatul Jannah, 'Pendidikan Agama Islam Berbasis Pesantren Dalam Peningkatan Kecerdasan Spiritual Siswa Di SMP Unggulan Al-Falah Pacul Bojonegoro', 1-19. 
perkembangan peserta didik dan kesesuaiannya dengan lingkungan, kebutuhan pembangunan nasional, perkembangan ilmu pengetahuan dan teknologi, serta sesuai dengan jenjang masing-masing satuan pendidikan ${ }^{8}$. Dengan adanya landasan tersebut maka inovasi kurikulum memiliki limit yang jelas dan tidak berbenturan dengan kepentingan yang lebih luas yakni kepentingan berbangsa dan bernegara. Berlandaskan hal ini maka jelas sudah bahwa inovasi pengembangan kurikulum sekolah berbasis pesantren membutuhkan perencanaan yang lebih matang dan optimal.

Untuk menghasilkan analisis yang mendetail, peneliti melakukan kajian awal terhadap penelitian lain yang memiliki relevansi dengan kajian materi yang sedang diteliti. Pada salah satu penelitian terdahulu Mursalim \& Hatta dalam judul "Inovasi Pengembangan Kurikulum PAI di Sekolah Menengah Pertama Raudatut Tholabah Berbasis Pesantren" mengatakan bahwa pelaksanaan inovasi pengembangan kurikulum PAI melalui kurekuler, pengintegrasian kurikulum sekolah dengan pesantren. Pengintegrasian ini dilakukan dengan memasukkan pelajaran kitab kuning Sedangkan inovasi pengembangan kurikulum PAI melalui ekstrakurikuler dilakukan dengan cara penguatan nilai-nilai keagaman melalui kegiatan doa bersama dan membaca Al-Qur'an, shalat Dhuha, shalat Dhuhur berjamaah, membaca asmaul husna?.

Selanjutnya Akmal Mundiri \& Reni Uswatun Hasanah dalam judul "Inovasi Pengembangan Kurikulum PAI di SMP Nurul Jadid" mengatakan bahwa inovasi pengembangan kurikulum PAI di SMP Nurul Jadid telah melakukan beberapa tindakan, yaitu (1) Pembinaan Furudul Ainiyah. Pembinaan furudul ainiyah dilakukan guru untuk meningkatkan tingkat pemahaman siswa terhadap materi yang berkaitan dengan Pendidikan Agama Islam (2) Membiasakan Disiplin Sholat Berjama'ah. Sebagaimana diketahui, sholat merupakan tonggak agama bagi umat Islam. (3) Kurikulum PAI yang berintegrasi dengan Madrasah Diniyah. Dalam hal ini Madrasah

${ }^{8}$ Hasan Baharun, 'Curriculum Developmnent Trouht Creative Lesson Plan', Jurnal Cendikia, 16.1 (2018), 43.

${ }_{9}$ Mursalim and Hatta. 
sangat berperan penting dalam menunjang keberhasilan Kurikulum Pendidikan Agama Islam ${ }^{10}$.

Dua penelitian diatas lebih menekankan pada integrasi kurikulum sekolah dan pesantren yang menghasilkan output yang baik, sedangkan penelitian ini menfokuskan pada peningkatakan minat masyarakat pada lembaga, hal ini yang menjadi pembeda. Penelitian inovasi pengembangan kurikulum sekolah berbasis pesantren nampaknya sangat menarik dan penting untuk dilakukan penelitian, tidak hanya sebagai sosialisasi pengembangan kurikulum sekolah berbasis pesantren, namun juga menganalisa sejauh mana pelaksanaan inovasi pengembangan kurikulum sekolah berbasis pesantren di SMP Islam, sedangkan inovasi pengembangan kurikulum sekolah berbasis pesantren memadukan kurikulum pesantren dengan kurikulum Departemen Pendidikan Nasional merupakan hal yang baru bagi lembaga swata yang ada dinauangan pesantren.

Inovasi yang dapat di buktikan siswa SMP Islam dalam jangka waktu tiga bulan siswa bisa baca kitab kuning dengan cepat dengan metode Amsilati akan tetapi disesuiakan dengan jengjang pendidikan siswa SMP Islam, dan ditambah dengan program tahfid qur'an yang diterapkan di SMP Islam serta memasukkan materi pembelajaran Pondok pesantren kedalam kurikulum SMP Islam di sumberranyar Paiton Probolinggo. Hal itu belum pernah dilakukan oleh sekolahsekolah umum lainnya.

SMP Islam merupakan salah satu sekolah yang menerapkan inovasi kurikulum sekolah berbasis pesantren tidak mengacu secara total terhadap kurikulum Departemen Nasional. Yang dikembangkan kurikulum SMP Islam meliputi kombinasi dari Departemen Nasional dengan kurikulum pesantren hal tersebut sulit dilakukan sekolah-sekolah lain, karena di butuhkan perencanaan yang matang dan tenaga pengajar yang professional.

Kurikulum kombinasi ini terbukti "Optimal" hal trsebut dapat meningkatkan kepercayaan masyarakat terhadap SMP Islam serta menghasilkan out

\footnotetext{
10 Akmal Mundiri and Reni Uswatun Hasanah, 'Inovasi Pengembangan Kurikulum PAI Di SMP Nurul Jadid', Tadrib: Jurnal Pendidikan Agama Islam, 4.1 (2018), 40-68 <https://doi.org/10.19109/tadrib.v4i1.1721>.
} 
put bagi siswa dan siswi SMP Islam Sumberranyar Paiton, telah tercatat beberapa kali siswa dan siswi meraih prestasi dalam berbagai olimpiade baik tingkat kecamatan maupun tingkat kabupaten dan tingkat provinsi.

Dapat dijelaskan bahwa inovasi kurikrikulum sekolah berbasis pesantren yang dikembangkan di SMP Islam Sumberranyar Paiton dan sistem lembaga yang dilakukan, program SMP Islam Sumberranyar Paiton yang di terapkan, dukungan dari pemerintahan serta masyarakat semua stick holder yang terlibat dapat mempengaruhi terhadap prestasi siswa hal ini di dukung oleh fasilitas yang memadai sarana yang baik. Prestasi yang raih oleh siswa dan siswi SMP Islam Sumberanyar Paiton Probolinggo. Hal tersebut dapat meningkatkan kepercayaan masyarakat terhadap kualitas dan muto pendidikan SMP Islam di bawah naungan yayasan Islamiyah Safiiyah.

Adanya inovasi kurikrikulum sekolah berbasis pesantren yang dikembangkan oleh SMP Islam Sumberranyar Paiton dan sistem yang dilakukan serta, program yang di terapkan serta dukungan pemerintahan serta masyarakat semua seticholder yang ada, turut mambantu mengembangkan kurikulum yang di kembangkan SMP Islam Sumberranyar Paiton Probolinggo. hal tersebut menjadi dasar tujuan pendidikan, baik tujuan pendidikan nasional maupun tujuan pendidikan Islam, maka sekolah berbasis pesantren yang di sebut dengan muatan lokal menjadi inovasi pendidikan yang ideal. sekolah berbasis pesantren atau muatan lokal sangat penting bagi pendidikan, terutama pendidikan di dalam lembaga pendidikan Islam sehingga mampu menambah keilmuan agama peserta didik.

Muatan lokal sekolah berbasis pesantren menjadi inovasi yang relevan dalam problematika saat ini. Dianggap relevan dan ideal karena mampu menjembatani model pendidikan pesantren yang sudah mulai tertinggal dan pesantren yang mulai kurang diminati oleh peserta didik ${ }^{11}$. Dengan adanya muatan lokal sekolah berbasi pesantren di SMP Islam, peserta didik bisa mempelajari beberapa mata pelajaran yang ada di pesantren tanpa harus masuk pesantren, serta muatan lokal sekolah berbasis pesantren ini bisa menjaga budaya-budaya pesantren yang sudah mulai ditinggalkan

${ }_{11}$ Muhammad Arif Syaifuddin and Eni Fariyatul Fahyuni, 'Penguatan Pendidikan Karakter Melalui Kurikulum Muatan Lokal Di SMP Muhammadiyah 2 Taman', PALAPA: Jurnal Studi Keislaman Dan Ilmu Pendidikan, 7.November (2019), 267-85. 
dan juga sangat relevan dengan lingkungan agamis tempat sekolah berada, kurikulum muatan lokal sekolah berbasis pesantren merupakan pembelajaran mata pelajaran yang diambil dari mata pelajaran yang ada di pesantren. Muatan lokal sekolah berbasis pesantren menurut peneliti merupakan inovasi yang sangat ideal dan diperlukan di masa sekarang. Karena pesantren sudah mulai ditinggalkan dan kurang diminati karena tergerus dengan keamajuan zaman. Pendidikan muatan lokal pesantren ini diharapkan mampu menjembatani dan menambah pengetahuan siswa tentang ilmu agama tanpa harus belajar di pesantren.hal tersebut di kembang di SMP Islam Sumberranyar Paiton Probolinggo.

Mengingat pentingnya kurikulum berbasis pesantren ini, maka peneliti bertujuan untuk mengetahui dan menganalisis inovasi pengembangan kurikulum sekolah berbasis pesantren dalam meningkatkan kepercayaan masyarakat di SMP Islam Sumberranyar Paiton Probolinggo. Hal ini dilakukan lantaran adanya perubahan pengembangan kurikulum Sekolah berbasis pesantren.

\section{METODE PENELITIAN}

Penelitian ini menggunakan pendekatan kualitatif, digunakan untuk mencari informasi yang lebih mendalam tentang inovasi pengembangan kurikulum sekolah berbasis pesantren dalam meningkatkan kepercayaan masyarakat, sedangkan jenis penelitian yang digunakan adalah studi kasus yang difokuskan pada kasus tertentu untuk diamati dan dianalisis secara cermat. sampai selesai. Peneliti mencoba mendeskripsikan dan menganalisis inovasi pengembangan kurikulum sekolah berbasis pesantren dalam meningkatkan kepercayaan masyarakat di SMP Islam Sumberranyar Paiton Probolinggo Jawa Timur Indonesia. Peneliti dalam hal ini terjun langsung ke lapangan dan berinteraksi dengan subjek penelitian secara aktif. Teknik pengumpulan data dilakukan melalui observasi dan wawancara mendalam. Sedangkan analisis data melalui tiga tahapan yaitu: reduksi data, penyajian data, dan verifikasi. 


\section{HASIL PENELITIAN DAN PEMBAHASAN}

\section{Inovasi Pengembangan Kurikulum Sekolah berbasis pesantren}

\section{1) Kurikulum Sekolah berbasis pesantren}

kurikulum sekolah berbasis pesantren yang dikembangkan oleh SMP Islam Sumberranyar Paiton merupakan inovasi SMP Islam Sumberranyar dalam upaya meningkatkan kualitas dan efektifitas SMP Islam Sumberranyar Paiton. Karena yang berperan dalam pengembangan suatu lembaga adalah peran pelaku yang bergerak di dalamnya.

Usaha yang di kembangkan di SMP Islam Sumberranyar Paiton sudah mengalami perkembangan yang sangat segnifikan. Hal itu tebukti dari banyaknya perubahan pada sistem pembelajaran di SMP Islam Sumberranyar Paiton tersebut. Pengelolaan kurikulum yang baik itu yang menjadikan prestasi SMP Islam Sumberranyar Paiton menjadi lebih maju dari tahun ke tahun. Perubahan tidak bisa tercipta tanpa adanya inovasi pengembangan dari kurikulum sekolah itu sendiri.

Kurikulum dalam hal ini justru menjadi kunci penting bagi pendidikan, yang tentunya berkaitan erat dengan proses pembelajaran sebagai aktifitas peserta didik dalam mengembangkan potensi yang dimiliki (afektif, koginitif, psikomotorik). Sehingga pendidikan akan melahirkan generasi muda yang berkualitas, berdaya tinggi, dan bisa berkompetensi secara elegan ${ }^{12}$.

Hal ini sesuai dengan visi dari pendidikan itu sendiri, sebagaimana tertuang UU 20 tahun 2003 tentang Sistem Pendidikan Nasional (SISDIKNAS). Dalam penjelasannya dikemukakan bahwa pendidikan nasional mempunya visi terwujudnya sistem pendidikan sebagai pranata sosial yang kuat dan berwibawa untuk memberdayakan semua warga negara

${ }^{12}$ Chusnul Muali, Adi Wibowo, and Zaini Gunawan, 'Pwsantren Dan Millenial Behaviour: Tantangan Pendidikan Pesantren Dalam Membina Karakter Santri Milenial', 3.2 (2020), 131-46. 
indonesia berkembang menjadi manusia yang berkualitas. Sehingga mampu dan proaktif menjawab tantangan zaman yang selalu berubah ${ }^{13}$.

Efektif dan tidaknya suatu pendidik tergantung kurikulum yang di kembangkan pada lembaga, kurikulum sekolah berbasis pesantren yang dikembangkan di SMP Islam dapat mempengaruhi terhadap perkembangan sekolah.

SMP Islam Sumberanyar Paiton bisa berkembang secara segnifikan karena adanya kurikulum yang baik. Kurikulum yang baik akan mampu menjadikan sistem pembelajaran yang baik. Sitem pembelajaran yang baik akan memperhatikan pada metode belajar mengajar serta hasil dari belajar mengajar itu sendiri.

Inovasi pengembangan kurikulum mulai berkembangn dengan baik. Sistem pengajaran yang dipakai dalam proses pembelajarannya adalah sistem pengajaran sekolah berbasis pesantren, pembelajaran di sini sudah mulai dilakukan inovatif sedangkan kurikulum sekolah berbasis pesantren adalah memadukan kurikulum pesantren dengan kurikulum Nasional. Dengan metode pembelajran diskusi, musyawarah, hafalan dan juga Metode cepat baca qitab kuning,(metode amsilati) Metode sorogan yang mutakhir ( gaya baru ) Siswa diberi tugas satu persatu pada waktu tatap muka yang terjadwal, setelah membaca diadakan pembahasan dengan cara berdialog dan berdiskusi sampai mendapatkan pemahaman yang jelas pada pokok bahasan $^{14}$.

Bila dikaitkan semua bahwa kurikulum merupakan rancangan pendidikan yang merangkum semua pengalaman belajar ${ }^{15}$. Dalam kurikulum terintegrasi filsafat, nilai-nilai, pengetahuan dan perbuatan pendidikan, kurikulum disusun oleh para ahli pendidikan, ahli kurikulum, ahli bidang

13 Sitti Nurfaidah Samad, 'Manajemen Mutu Pendidikan Berbasis Pesantren (Studi Kasus MA AlMawaddah Warrahmah Kolaka), Jurnal Teknologi Pendidikan Madrasah, 2.1 (2019), 70-88 <https://doi.org/10.5281/zenodo.2575112>.

14 Totok Mulyadi, 'Hasil Wawancara Pada Tanggal 03 Maret 2021'.

15 Elfa Tsuroyya, 'Manajemen Kurikulum Pesantren Berbasis Madrasah Di MAN 3 Sleman Yogyakarta', MANAGERIA: Jurnal Manajemen Pendidikan Islam, 2.2 (2017), 379-410 <https://doi.org/10.14421/manageria.2017.22-09>. 
ilmu pendidikan, pejabat pendidikan, pengusaha serta unsure-unsur masyarakat lainnya.

Sebagai sebuah lembaga pendidikan yang secara struktural harus tunduk pada regulasi yang ditetapkan oleh otoritas pemerintah, SMP Islam Sumberanyar Paiton tidak terlepas dari dinamika perubahan kurikulum secara nasional. Sedikitnya sudah empat kali pergantian kurikulum dalam skala nasional yang dialami di SMP Islam Sumberanyar Paiton, terhitung sejak pesantren ini berdiri pada tahun 1994 hingga tahun 2021, kurikulum yang menekankan keterpaduan antara tiga lingkungan pendidikan, yaitu lingkungan sekolah, keluarga dan masyarakat.

\section{2) Komponen-komponen Pengembangan Kurikulum di SMP Islam}

SMP Islam Sumberanyar Paiton memiliki kurikulum terpadu antara kurikulum pesantren dan kurikulum pendidikan nasional yang terpadu dalam satu sistem yang integral. Implikasi dari model kurikulum ini adalah penyelenggaraan pendidikan yang mengikuti konsep pendidikan nasional.

SMP Islam Sumberanyar Paiton dalam mengembangkan kurikulumnya juga menerapkan prinsip-prinsip ‘paten’ tersebut di samping juga mengedepankan 'inovasi’ mandiri. Hal yang terakhir ini dimungkinkan terjadi karena secara geologis sistem pendidikan yang berlaku di sekolah berbasis pesantren dapat dijadikan tolak ukur dengan lembaga pendidikan pada umumnya.

\section{3) Orientasi dan Tujuan Kurikulum sekolah berbasis Pesantren}

Keberadaan sekolah berbasis pesantren yang disebut-sebut sebagai pendidikan Islam tertua khususnya pesantren yang ada di nusantaram telah memberikan warna tersendiri pada orientasi keagamaan masyarakat lokal. Pesantren bukan saja menjadi pilar terdepan saat bangsa Indonesia terkoyak oleh kaum imperialis sampai akhirnya founding fathers memproklamirkan kemerdekaan negeri ini, tapi juga merupakan satusatunya lembaga pendidikan yang mampu survive melintasi batas generasi, 
budaya, social dan politik hingga saat ini hanya dengan pola pendidikannya yang sangat sederhana, termarjinal, dan bahkan sangat kesulitan dari sisi pendanaan ${ }^{16}$.

Realitas tersebut seolah menuntun SMP Islam Sumberanyar Paiton sekolah berbasis pesantren hal itu untuk mempertahankan jati diri sebagai lembaga pendidikan Islam dengan tetap berusaha inovatif dalam mengelola pola pengajarannya agar senantiasamseiring dengan perkembangan paradigma pendidikan. Guna melanggengkan hal tersebut maka sekolah ini kemudian merumuskan tujuan-tujuan pendidikannya yang selaras dengan nilai-nilai dan tradisi pesantren

\section{Faktor Pendukung dan penghambat Inovasi pengembangan kurikulum sekolah berbasis pesantren}

Keberhasilan suatu sekolah sangat bergantung pada kurikulum yang dikembangkannya, karena kurikulum sebagai acuan atau seperangkat rencana dan pengaturan mengenai isi dan bahan pelajaran dalam kegiatan belajar mengajar. untuk mengembangkan kurikulum sekolah, hal itu dapat diartikan bahwa semua kegiatan yang ada dalam lingkungan Pondok pesantren merupakan kurikulum pendidikan sekolah berbasis pesantren yang dijalankan guna mencapai tujuan pendidikan dan pengajaran seperti yang diharapkan ${ }^{17}$. Kemudian SMP Islam Sumberranyar Paiton dalam kurun waktu tertentu secara rutin meninjau ulang kurikulum pengajarannya dengan pertimbangan-pertimbangan matang demi peningkatan kualitas pendidikan yang ada di SMP Islam Sumberranyar Paiton.

Inovasi pengembangan kurikulum sekolah berbasis pesantren yang di lakukan oleh SMP Islam Sumberranyar Paiton, tujuannya untuk mengembangkan Inovasi pengembangan kurikulum sekolah berbasis pesantren, dari pihak Pondok Pesantren Islamiyah Safiiyah khususnya pengasuh KH.Fauzi Imron, Lc.M. Sc mendukung kurikulum yang dikembangkan oleh sekolah, kepala sekolah SMP Islam

${ }^{16}$ Ulfah Rahmawati, 'Pesantren: Lembaga Pendidikan Berbasis Masyarakat (Tinjauan Pasal 1 Ayat 4 PP Nomor 55 T Ahun 2007 Tentang Pendidikan Agama Dan Pendidikan Keagamaan)', PALAPA: Jurnal Studi Keislaman Dan Ilmu Pendidikan, $11.2 \quad$ (2018), 443-66 <https://doi.org/10.21043/jupe.v11i2.3490>.

17 Tsuroyya. 
Sumberranyar Paiton bapak Nasiruddin. melibatkan semua stecholder yang ada, dan pihak yang terkait, pengurus, komite, dewan guru, tokoh masyarakat wali murid di libatkan dalam mengembangkan kurikulum sekolah berbasis pesantren di SMP Islam Sumberranyar Paiton Probolinngo.

Dari hasil wawancara peneliti menganalisis bahwa Inovasi yang di kembangkan oleh sekolah ini, pihak sekolah selalu melibatkan semua pihak-pihak terkait, komete, pengurus, dewan guru wali murid dan tokoh masyarakat tiap tahun ajaran baru,hal itu upaya SMP Islam Sumberranyar Paiton untuk mengembangkan kurikulum sekolah bersama-sama, dalam rangka semua kegiatan yang ada dalam lingkungan pesantren merupakan kurikulum sekolah berbasis pesantren yang dijalankan guna mencapai tujuan pendidikan dan pengajaran seperti yang diharapkan. Kemudian sekolah ini dalam kurun waktu tertentu secara rutin meninjau ulang kurikulum pengajarannya dengan pertimbangan-pertimbangan matang demi peningkatan kualitas pendidikan yang ada di likungangn pondok pesantren Islamiyah Safiiyah. Pengurus dan seggenap dewan guru SMP Islam Sumberranyar Paiton berusaha untuk mengembangkan kurikulum sekolah berbasis pesantren. hal Ini juga didukung oleh hasil observasi peneliti dan wawancara penulis dengan kepala sekolah SMP Islam Sumberranyar Paiton.

Dari wawancara di atas dianalisis untuk memenuhi tujuan pendidikan dan mengembankan kurikulum sekolah, dari observasi yang peneliti lakukan tentang faktor pendukung Inovasi pengembang kurikulum sekolah berbasis pesantren adalah dengan melibatkan semua pihak-pihak yang terkait dalam mengembangkan kurikulum secara bersama-sama untuk menghasilkan kurikurilum yang optimal demi tercapai inovatif pembelajaran yang efektif dan menyenangkan.

Di SMP Islam Sumberranyar Paiton mulai awal didirikannya sekolah banyak siswa yang mempunyai tekad untuk belajar dengan rajin. Dengan sungguh-sungguh atas kesadaran pribadi dari diri siswa-siswi yang sangat tinggi untuk belajar. Hal itu di dukung oleh program yang dikembangkanya dan fasilitas yang memadai serta pengelolaan kurikulum yang di kembangkan di SMP Islam Sumberranyar Paiton.

Dari hasil wawancara peneliti menganalisis betapa pentingnya inovasi pengembangan kurikulum sekolah berbasis pesantren yang di kembangkan di SMP 
Islam Sumberranyar Paiton agar sistem pendidikan lebih terarah. Orientasinya adalah peningkatan mutu pendidikan pada sekolah lebih optimal. Itulah alasan mengapa kurikulum menjadi sangat penting untuk diperbaharui, sebab ia merupakan ‘jantung' bagi jalannya pendidikan.

Dari penjelasan bapak Totok Mulyadi selaku pengelola kurikulum bahwa kurikulum dapat diposisikan sebagai ruh sebuah proses pendidikan sebuah lembaga pendidikan. Analogi ini cukup beralasan sebab tanpa rancangan pembelajaran yang sistematis maka sebuah lembaga pendidikan menjadi tidak memiliki tujuan yang jelas. Pendidikan yang berlangsung dalam suatu institusi pendidikan biasanya akan bertumpu pada beberapa program yang meliputi tujuan, metode, dan langkah-langkah pendidikan dalam membina suatu generasi untuk disiapkan menjadi generasi yang lebih baik dari sebelumnya ${ }^{18}$.

Dalam konteks yang lebih sederhana kurikulum adalah sejumlah mata pelajaran yang harus ditempuh oleh murid untuk memporoleh ijazah. Salain itu kurikulum juga ditujukan untuk mengantarkan anak didik pada tingkatan pendidikan, prilaku, dan intelektualitas yang diharapkan menjadikan mereka sebagai sosok anggota masyarakat yang berguna bagi bangsa dan masyarakatnya, serta mau berkarya bagi pembangunan bangsa dan perwujudan idealisme positif ${ }^{19}$.

Dari penjelasan ustadz Jakfar ${ }^{20}$ dapat dianalisis bahwa sebenarnya faktor pendukung inovasi pengembangan kurikulum sekolah adalah terlibatnya semua setecholder yang ada khususnya dewan guru sebab guru tersebut yang menjalankan kurikulum di lembaga karena guru merupakan ujung tombak yang terlibat langsung dengan peserta didik.

Selanjutnya kemaungan yang keras dari dalam diri guru juga sangat membantu untuk mengembangkan kurikulum. karena guru merupakan pengelola langsung dalam proses belajar mengajar, dari kemauan untuk mengembangkan kemampuan dalam segi keilmuan mengajarnya, ataupun bahkan dengan

\footnotetext{
${ }^{18}$ Mulyadi.

19 Muhammad Nasir, 'Pengembangan Kurikulum Berbasis Madrasah', HUNAFA: Jurnal Studia Islamika, 6.3 (2009), 273 <https://doi.org/10.24239/jsi.v6i3.138.273-300>.

20 'Wawancara Dengan Ustad Jakfar Pada Tanggal 03 Maret 2021', Jakfar.
} 
mengembangkan pola pembelajaran dengan yang efektif dan menyenangkan sesuai deng kurikulum yang dikembangkan bersama ${ }^{21}$.

Dari penjelasan Bapak Totok mulyadi ${ }^{22}$ selaku pengelola kurikulum dapat dianalisis bahwa yang menjadi penghambat kurikulum muatan lokal adalah alokasi waktu satu jam dalam satu minggu sedangkan yang menjadi factor penghambat lainnya dalam pembelajaran Nahwu sorof yaitu terdapat beberapa peserta didik yang sama sekali tidak mengerti atau belum mengenal pelajaran Nahwu, sehingga sangat kesulitan menerima materi pembelajaran, hal yang sangat peling dominan ditemukan dalam suatau pendidikan adalah kesadaran guru dalam mengembangkan perangkat pembelajarannya sehingga sering kali meleceng dari pokok pembahasan dalam proses belajar mengajar adalah dari segi guru tersebut, dari kurangnya motivasi untuk maju dengan cara belajar sendiri, kurang dapat menguasai teknologi informasi, malas dalam kegiatan-kegiatan seperti penataran, selanjutnya adalah guru yang usianya sudah cukup tua, hal ini akan menjadi penghambat di karenakan dengan usia yang lanjut guru akan sulit dalam proses peningkatan kompetensi dalam menunjang pembelajaran.

Dari faktor pendukung dan penghambat kurikulum sekolah perlu di evaluasi untuk mengetahui tujuan pendidikan untuk mengembangakan pendidikan yang lebih baik sesuai dengan harapan sekolah.

Salah satu bagian kurikulum yang terkait dengan penilaian untuk mengetahui seberapa jauh tujuan-tujuan pendidikan yang telah dicapai, adalah evaluasi ${ }^{23}$. Dengan adanya kontinyuitas evaluasi terhadap kurikulum maka akan dapat disimpulkan apakah tingkat pencapaian yang diharapkan tergolong rendah, standar, atau bahkan mengalami penurunan. Bila yang terakhir ini terjadi, maka harus dilakukan koreksi secepat mungkin agar titik persoalan dapat diidentifikasi dan dicarikan solusi

${ }^{21}$ Nasri, 'Studi Tentang Penerapan Strategi Guru PAI Dalam Meningkatkan Mutu Pembelajaran Pendidikan Islam Di MTs Az-Zuhriyah Hamzanwadi NW Tanjung Labuhan Haji Lombok Timur', PALAPA: Jurnal Studi Keislaman Dan Ilmu Pendidikan.

${ }^{22}$ Mulyadi.

23 Sumarni Sumarni, 'Evaluasi Implementasi Kurikulum 2013 Di Madrasah', EDUKASI: Jurnal Penelitian Pendidikan Agama Dan Keagamaan, 15.3 (2017), 45-57 $<$ https://doi.org/10.32729/edukasi.v15i3.453>. 
yang tepat demi peningkatan mutu kurikulum ${ }^{24}$. Namun demikian, evaluasi tetap dibutuhkan meskipun tidak terjadi 'trouble' dalam kurikulum.

\section{Meningkatnya Kepercayaan Masyarakat atas prestasis yang diraih oleh SMP} Islam

Keberhasilan suatu sekolah sangat bergantung pada kurikulum yang dikembangkannya, karena kurikulum sebagai acuan atau seperangkat rencana dan pengaturan mengenai isi dan bahan pelajaran dalam kegiatan belajar mengajar. untuk mengembangkan kurikulum sekolah, hal itu dapat diartikan bahwa semua kegiatan yang ada dalam lingkungan Pondok pesantren merupakan kurikulum pendidikan sekolah berbasis pesantren yang dijalankan guna mencapai tujuan pendidikan dan pengajaran seperti yang diharapkan ${ }^{25}$. Kemudian SMP Islam Sumberranyar Paiton dalam kurun waktu tertentu secara rutin meninjau ulang kurikulum pengajarannya dengan pertimbangan-pertimbangan matang demi peningkatan kualitas pendidikan yang ada di SMP Islam Sumberranyar Paiton.

Inovasi Pengembangan kurikulum Sekolah berbasis pesantren membuahkan hasil yang sangat segnifikan hal ini dengan terbuktinya prestasi - prestasi yang daraih tiap tahunnya oleh siswa-siswi SMP Islam Sumberanyar Paiton baik di tingkat Kecamatan, Kabupaten, Propensi hal itu membuktikan inovasi yang di kembangkan di SMP Islam Sumberanyar Paiton berhasil dengan baik

Dengan adanya Inovasi pengembangan kurikulum sekolah berbais pesantren yang di kembangkan di SMP Islam Sumberanyar Paiton menghasilkan kualitas dan uotput yang baik dan membuat belajar siswa menjadi lebih optimal, menat belajar santri lebih meningkat,sehingga usaha yang di kembangkan di SMP Islam

${ }^{24}$ Lalu A. Hery Qusyairi, 'Pengembangan Alat Evaluasi Psikomotor SMP Berdasarkan Kurikulum Tingkat Satuan Pendidikan (KTSP)', PALAPA : Jurnal Studi Keislaman Dan Ilmu Pendidikan, 4.2 (2016), 14-33 < https://doi.org/10.36088/palapa.v4i2.21>.

25 Sirajun Nasihin, 'Implementasi Kurikulum 2013 Di MTs Yaqin 1 Kwang Rundun Kecamatan Jerowaru (Masalah Dan Solusinya', Palapa: Jurnal Studi Keislaman Dan Ilmu Pendidikan, 4.1 (2016), 58-86 $</$ citations?view_op=view_citation\&continue $=/$ scholar $\% 3 \mathrm{Fhl} \% 3 \mathrm{Dpt}-$ BR\%26as_sdt $\% 3 \mathrm{D} 0,5 \% 26$ scilib\%3D1\&citilm=1\&citation_for_view=wS0xi2wAAAAJ:2osOgNQ5q $\mathrm{MEC} \& \mathrm{hl}=\mathrm{pt}-\mathrm{BR} \& \mathrm{i}=\mathrm{p}>$. 
Sumberanyar Paiton menghasilkan siswa-siswi yang berprestasi baik di kanca propensi maupun di tingkat kabupaten lebih-lebih di tingkat kecamatan.

Dari penjelasan Bapak Nasirudden ${ }^{26}$ selaku kepala Seklah SMP Islam Sumberanyar Paiton dapat dianalisis inovasi pengembangan kurikulum sekolah berbasis pesantren yang diterapkan di Islam Sumberanyar Paiton cukup berhasil. Oleh karena itu, melihat tantangan yang makin berat dalam dunia pendidikan, maka tugas pesantren saat ini terus berusaha memacu diri untuk selalu melakukan perbaikan dan perubahan baru demi kemajuan pendidikan. Tuntutan akan pentingnya perubahan ini harus disadari oleh semua unsur pelaksana pendidikan, Pengurus,komite, dukungan dari pengasuh serta peran dewan guru yang aktif dalam mengembakan minat belajar siswa

\section{KESIMPULAN}

Berdasarkan hasil penelitian diatas dapat disimpulkan bahwa Inovasi pengembangan kurikulum sekolah berbasis pesantren di SMP Islam mengalami peningkatan yang sangat baik, dari pengembangan kurikulum sekolah berusaha mengembangkan kurikulum pesantren dengan merubah sistem pembelajaran, Salah satu sekolah yang menerapkan inovasi kurikulum sekolah berbasis pesantren tidak mengacu secara total terhadap kurikulum Departemen Nasional, Faktor pendukung inovasi pengembangan kurikulum sekolah berbasis pesantren di SMP Islam antara lain kepala sekolah merlibatkan semua stakeholder yang terkait baik pengurus,segenap dewan guru tokoh masyarakat wali murid serta dukungan dari pengasuh pondok pesantren K.H. Fauzi Imron .Lc. M.Sc. Sedangkan yang paling urgen faktor penghambat inovasi pengembangan kurikulum sekolah berbasis pesantren di SMP Islam rendahnya kesadaran guru untuk mengembangkan perangkat pembelajaran hal ini menghambat Inovasi pengembangan kurikulum sekolah berbasis pesantren yang di kembangkan bersama di SMP Islam Sumberanyar Paiton, dan Inovasi pengembangan kurikulum sekolah berbasis pesantren yang di kembangkan di SMP Islam Sumberanyar Paiton dalam meningkatkan minat dan

${ }^{26}$ Nasirudden, 'Wawancara Dengan Nasirudden Pada Tanggal 03 Maret 2021'. 
prestasi belajar siswa, sedangkan dampak positif Inovasi kurikulum yang di kembangkan di SMP Islam dapat Meningkatan kepercayaan masyarakat pada SMP Islam Sumberanyar Paiton Probolinggo.

Dengan adanya penelitian ini, maka bisa memberikan dampak dan diimplementasikan sebagai pertimbangan dalam meningkatkan inovasi pengembangan kurikulum sekolah berbasisi pesantren di SMP Islam Sumberanyar Paiton.

\section{DAFTAR PUSTAKA}

Baharun, Hasan, 'Curriculum Developmnent Trouht Creative Lesson Plan', Jurnal Cendikia, 16.1 (2018), 43

Halil, Hermanto, 'Inovasi Kurikulum Pesantren Dalam Memproyeksikan Model Pendidikan Alternatif Masa Depan', Studi Keislaman, 1.2 (2015), 1-23

Huda, Nurul, 'Manajemen Pengembangan Kurikulum', Al-Tanæim: Jurnal Manajemen Pendidikan Islam, 1.2 (2017), 52-75 <https://doi.org/10.33650/altanzim.v1i2.113>

Kusnandi, Kusnandi, 'Integrasi Kurikulum Berbasis Pesantren Pada Lembaga Pendidikan', Jurnal Kependidikan, 5.2 (2017), 279-97 <https://doi.org/10.24090/jk.v5i2.2138>

Moch. Sya'roni Hasan, and Nur Arifatul Jannah, 'Pendidikan Agama Islam Berbasis Pesantren Dalam Peningkatan Kecerdasan Spiritual Siswa Di SMP Unggulan Al-Falah Pacul Bojonegoro', 1-19

Muali, Chusnul, Adi Wibowo, and Zaini Gunawan, 'Pwsantren Dan Millenial Behaviour: Tantangan Pendidikan Pesantren Dalam Membina Karakter Santri Milenial', 3.2 (2020), 131-46

Muhtifah, Lailial, 'Pola Pengembangan Kurikulum Pesantren Kasus Al-Mukhlishin Mempawah Kalimantan Barat', Jurnal Pendidikan Islam, 27.2 (2016), 203 $<$ https://doi.org/10.15575/jpi.v27i2.507>

Mulyadi, Totok, 'Hasil Wawancara Pada Tanggal 03 Maret 2021'

Mundiri, Akmal, and Reni Uswatun Hasanah, 'Inovasi Pengembangan Kurikulum PAI Di SMP Nurul Jadid', Tadrib: Jurnal Pendidikan Agama Islam, 4.1 (2018), 40 $68<$ https://doi.org/10.19109/tadrib.v4i1.1721>

Mursalim, and Hatta, 'Inovasi Pengembangan Kurikulum PAI Di Sekolah Menengah Pertama Raudatut Tholabah Berbasis Pesantren', Journal of Islamic Education Research, 1.02 (2020), 1-14 <https://doi.org/10.35719/jier.v1i02.23>

Mustofa, Ali, 'Perkembangan Kurikulum Pendidikan Agama Islam Di Pesantren, Madrasah Dan Sekolah', Jurnal Pikir: Jurnal Studi Pendidikan Dan Hukum Islam, 1.2 (2015), 89-121

Nasihin, Sirajun, 'Implementasi Kurikulum 2013 Di MTs Yaqin 1 Kwang Rundun 
Kecamatan Jerowaru (Masalah Dan Solusinya', Palapa: Jurnal Studi Keislaman Dan Ilmu Pendidikan, 4.1 (2016), 58-86 $</$ citations?view_op=view_citation\&continue $=/$ scholar $\% 3$ Fhl $\% 3 \mathrm{Dpt}-$ BR $\% 26$ as_sdt $\% 3 \mathrm{D} 0,5 \% 26 \mathrm{scilib} \% 3 \mathrm{D} 1 \&$ citilm $=1 \&$ citation_for_view $=\mathrm{wS} 0 \mathrm{xi} 2 \mathrm{w}$ AAAAJ:2osOgNQ5qMEC\&hl=pt-BR\&oi $=$ p>

Nasir, Muhammad, 'Pengembangan Kurikulum Berbasis Madrasah', HUNAFA: $\begin{array}{llll}\text { Jurnal Studia } \quad \text { Islamika, } & 6.3 & \text { (2009), } & 273\end{array}$ $<$ https://doi.org/10.24239/jsi.v6i3.138.273-300>

Nasirudden, 'Wawancara Dengan Nasirudden Pada Tanggal 03 Maret 2021'

Nasri, 'Studi Tentang Penerapan Strategi Guru PAI Dalam Meningkatkan Mutu Pembelajaran Pendidikan Islam Di MTs Az-Zuhriyah Hamzanwadi NW Tanjung Labuhan Haji Lombok Timur', PALAPA : Jurnal Studi Keislaman Dan Ilmu Pendidikan

Nurlaeli, Acep, 'Inovasi Pengembangan Kurikulum Pendidikan Agama Islam Pada Madrasah Dalam Menghadapi Era Milenial', Wahana Karya Ilmiah, 4.2 (2020), 622-44

Qusyairi, Lalu A. Hery, 'Pengembangan Alat Evaluasi Psikomotor SMP Berdasarkan Kurikulum Tingkat Satuan Pendidikan (KTSP)', PALAPA: Jurnal Studi Keislaman Dan Ilmu Pendidikan, $4.2 \quad$ (2016), 14-33 $<$ https://doi.org/10.36088/palapa.v4i2.21>

Rahmawati, Ulfah, 'Pesantren: Lembaga Pendidikan Berbasis Masyarakat (Tinjauan Pasal 1 Ayat 4 PP Nomor 55 T Ahun 2007 Tentang Pendidikan Agama Dan Pendidikan Keagamaan)', PALAPA : Jurnal Studi Keislaman Dan Ilmu Pendidikan, 11.2 (2018), 443-66 < https://doi.org/10.21043/jupe.v11i2.3490>

Sitti Nurfaidah Samad, 'Manajemen Mutu Pendidikan Berbasis Pesantren (Studi Kasus MA Al- Mawaddah Warrahmah Kolaka)', Jurnal Teknologi Pendidikan Madrasah, 2.1 (2019), 70-88 < https://doi.org/10.5281/zenodo.2575112>

Sumarni, Sumarni, 'Evaluasi Implementasi Kurikulum 2013 Di Madrasah', EDUKASI: Jurnal Penelitian Pendidikan Agama Dan Keagamaan, 15.3 (2017), 45-57 $<$ https://doi.org/10.32729/edukasi.v15i3.453>

Syaifuddin, Muhammad Arif, and Eni Fariyatul Fahyuni, 'Penguatan Pendidikan Karakter Melalui Kurikulum Muatan Lokal Di SMP Muhammadiyah 2 Taman', PALAPA : Jurnal Studi Keislaman Dan Ilmu Pendidikan, 7.November (2019), 26785

Tsuroyya, Elfa, 'Manajemen Kurikulum Pesantren Berbasis Madrasah Di MAN 3 Sleman Yogyakarta', MANAGERLA: Jurnal Manajemen Pendidikan Islam, 2.2 (2017), 379-410 <https://doi.org/10.14421/manageria.2017.22-09>

'Wawancara Dengan Ustad Jakfar Pada Tanggal 03 Maret 2021', Jakfar 